\title{
亜熱帯沖縄における住宅建築および室内熱環境の変遷に関する研究 A STUDY ON HISTORICAL CHANGES OF RESIDENTIAL HOUSES AND THEIR INDOOR THERMAL ENVIRONMENTS IN SUBTROPICAL OKINAWA
}

\author{
新川亮樹*1, 堤 純一郎*2, 仲松 亮*3 \\ Ryoki ARAKAWA, Jun-ichiro TSUTSUMI and Ryo NAKAMATSU
}

\begin{abstract}
Historical changes of residential houses and their indoor thermal environments are investigated in this paper. Six residential houses that have various location, structures and historical background from 18th century to the present time in subtropical Okinawa were selected for the full-scale measurement of indoor thermal environments. Diurnal fluctuations of indoor air temperature data without air-conditioning on one summer day were compared with outdoor data in each measurement house, and the temperature differences between indoor and outdoor were examined with solar radiation and wind speed data. Indoor thermal environments in old wooden houses are not so bad, however it is getting worse in ordinary RC houses, and then it is improved in an energy conservation house with ventilated double skin walls.
\end{abstract}

Keywords: Historical changes, Residential houses, Indoor thermal environment, Full-scale measurement, Subtropical Okinawa 歴史的変遷，住宅，室内熱環境，実測調査，西熱带沖縄

1. はじめに

現代では, 建物において空調機器などの人工的な制御を積極的に 取り入れ，居住環境を快適に保つことは一般的である。一方，地球 温暖化対策のために住宅の省エネルギー化が政策的に急速に進めら れているという状況にもある。省エネルギーでありながら快適な生 活環境を維持することは, 建築環境工学が抱えている究極の命題で あり，そのために多くの研究が行われてきている。

最近の住宅における熱環境とエネルギー問題解決の方向は, 高断 熱・高気密化に向かって進んでいる。これは人工的な環境制御を前 提として, 主として暖房を中心とする地域において, 非常に有効な 手段と考えられる。沖縄においても高断熱・高気密化の傾向が見ら れるが, 蒸暑地域では必ずしも有効な手段とは言えず, 例えば高気 密化による室内のカビの発生等の問題を誘発している。沖縄の住宅 事情を顧みると, 台風やシロアリへの対策から RC 造へのあこがれ のような感情があり, 蒸暑環境や室内空気質への対応は, 空調機器 に頼って進められてきた。しかし，最近になってそれが真に快適な 居住環境であるか, また省エネルギー化を満足しているか疑問が呈 されている。

住宅の熱環境に関する研究はこれまでに多数の報告がある。蒸暑 地域での研究も多く見られるが, 近年の傾向である断熱気密化に伴 う影響に関するものが多い1123)。また, 地中冷熱や換気を利用した パッシブクーリングに関する研究も見られる45)61。伝統的な民家 の熱環境に関する研究も行われており7), 沖縄においても伝統的な 民家と RC 造住宅の熱環境の比較が行われている8 9)。
本研究は, 亜熱帯の蒸暑気候である沖縄において, 18 世紀中頃に 建造された民家から現代のパッシブクーリングシステムを持つ住宅

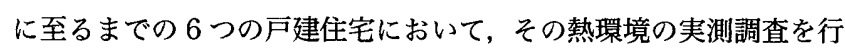
い, 住居形式の変遷にともなって建物の熱的な性能がどのように変 化してきたかを検証するものであり,これからの健康的でエネル ギー効率の高い住宅作りのための基整データの構築を目的とするも のである。

\section{2. 沖縄における居住環境の特徵}

\section{1 住居形態の変遷}

沖縄における住居は，垂木 (リン) 構造の蒏苗屋根と掘建て中柱 (ナカバーヤ) を持つ穴屋 (アナヤー) がその原形とされる注1)。その 後, 住居形態は第二次世界大戦前まで貫木屋 (ヌチジャー), 茅亘貫 屋 (カヤヤー), 赤瓦貫屋 (カーラヤー) と発展するが, 森林に乏し く大材入手の困難な沖縄では, 1889 年 (明治 22 年) まで続いた林 政によって 17 世紀以降用材の制限が行われ，一般に云われる穴屋 から貫木屋までの系譜は貧困である。戦後 1959 年, 琉球開発金融 公社設立とともに住居形態はセメント瓦屋, さらに貫木屋平面を継 承する RC 造住宅へと移行する10)。これは大戦によって殆ど焼失し た状態の中, 米軍供給の $2 \times 4$ 工法の応急的住宅が台風の襲来によつ て壊滅的な被害を受けたため, 米軍主導の下に「耐風恒久建築」とさ れた $\mathrm{CB}$ 造, $\mathrm{RC}$ 造建築が主流となったものである11。実際に $\mathrm{CB}$ 造, $\mathrm{RC}$ 造が建てられたのは戦後 4 5 年経ってからであり, 在日米陸軍 技術本部によるものである ${ }^{12)}$ 。当時, 米軍管理下の蚁縄では, 軍人

\footnotetext{
${ }^{* 1}$ 琉球大学大学院理工学研究科 大学院生 $\cdot$ 修士 (工学)

Graduate Student, Graduate School of Engineering Sciences, University of the Ryukyus, M. Eng.

*2 琉球大学工学部環境建設工学科 教授 $\cdot$ 工博

$* 3$ 那龩市役所 臨時職員 $\cdot$ 博士 (工学) 
軍属家族の住宅供給のために外人住宅と呼ばれる $\mathrm{CB}$ 造または RC 造住宅が多数建設され，最盛期には 1 万戸を超える規模まで增加し

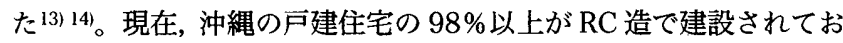
ク，ピロティ建築の占める割合が比較的高い注22のも現在の沖縄に おける住宅事情の特徽である ${ }^{15)}{ }^{16)}$ 。

\section{2 地上気象の様子}

沖縄気象台（那羁・26 $6^{\circ} 12.2^{\prime} \mathrm{N}, 127^{\circ} 41.3^{\prime} \mathrm{E}$ ，標高 $28.1 \mathrm{~m}$ ）におけ る主な気象要素の月別平年值を図 1 に示す。年平均気温が $22.7^{\circ} \mathrm{C}$ で, 最高気温の月別平年值も 1 月と 2 月を除いて $20^{\circ} \mathrm{C}$ 以上と高い值 である。また, 相対湿度も平年值で $65 \%$ を下回る月はなく, 蒸暑気 候の特徴が表れている。

\section{3. 実測対象の住宅および実測の概要}

各測定対象住宅における測定項目を表 1 ，測定対象住宅の概要を 表 2 に示す。また, 各測定対象住宅の外観を図 2 , 外気温度と室内 温度の測定点の配置を図 3 に示す。各住宅の測定において外気温 度, 室内温度ともに多数の測定点が設定されているが, 外気温度に ついては全ての測定点の測定結果について検討を行い，最も代表的 な值を示している測定点を選出している。 $\mathrm{B}$ 邸， $\mathrm{C}$ 邸， $\mathrm{E}$ 邸は居住 者が生活している状態での測定であるが， A 邸，F 邸は展示住宅で あり，D 邸は事務所として使用されているため，それぞれ日中に人 の出入りがある。測定期間中，全ての住宅において空調機の使用は 無く, $\mathrm{B}$ 邸に付随する $\mathrm{RC}$ 造の物置を除く全ての住宅において空を 開けた状態で測定している。

$3.1 \mathrm{~A}$ 邸

北中城村に位置する住宅で，建築構造は鎌倉・室町時代の日本建 築の流れを汲むが，各部に特殊な手法が加えられた独特な一階建て の住居建築である (図 $2[\mathrm{~A}]$ )。現存する建物は 18 世紀中頃に建て られたと伝えられている。当時の屋敷構えがそっくり残っている 例は沖縄本島内ではきわめて珍しく，士族屋敷の形式に農家の形式 である高倉, 納屋, 畜舎等が付随して沖縄の住居建築の特色をすべ て備え持っている。そのため 1956 年に琉球政府から，1972 年に 日本政府から国の重要文化財に指定されている。

2001 年 7 月 18 日から 22 日までの期間, 自己記録型温湿度計に よる室内温度・湿度，外気温度・湿度，グローブ温度，放射温度計 による表面温度，熱式風速計による風速の測定を行っている。 $3.2 \mathrm{~B}$ 邸

うるま市に位置する住宅で, 平面計画的には $\mathrm{A}$ 邸と同様の形式を 持つ。基本的には木造だが, 壁面と浴室, 台所全体にコンクリート ブロックが使用されたセメント瓦堇一階建てである (図 $2[\mathrm{~B}]$ )。着 工された当時は赤瓦が主流であったが，それ以後はセメント瓦が急 速に増加していく。敷地内に井戸，畜舎があり，沖縄の伝統的な民 家の形態を残した戦後の一般的な住宅である。
1995 年 8 月 31 日から 9 月 4 日までの期間, $\mathrm{T}$ 型熱電対による室 内温度, 外気温度, グローブ温度, また隣接する一階建て RC 造物置 屋上においてプロペラ型風速計による風向・風速，ネオ型全天日射 計による日射量の測定を行っている。なお， $\mathrm{RC}$ 造の物置も此較の ため測定を行っている。

3.3 C 邸

宜野湾市に位置する RC 造一階建ての住宅である (図 $2[\mathrm{C}]$ )。外 人住宅と呼ばれる住宅で, 1950 年代に建てられ 50 年以上経過する 現在も補修されながら使用されている。玄関ポーチに花ブロックが 使用されているのが特徵的で, 天井や内装の無い RC 単層壁である。 現在の沖縄における住宅の主流である $\mathrm{RC}$ 造住宅の原型である。

2006 年 6 月 29 日から 9 月 7 日までの期間, 自己記録型温湿度計 による室内温度・湿度, 外気温度・湿度の測定を行っている。

$3.4 \mathrm{D}$ 邸

宜野湾市に位置する RC 造二階建ての住宅である (図 $2[\mathrm{D}]$ )。二

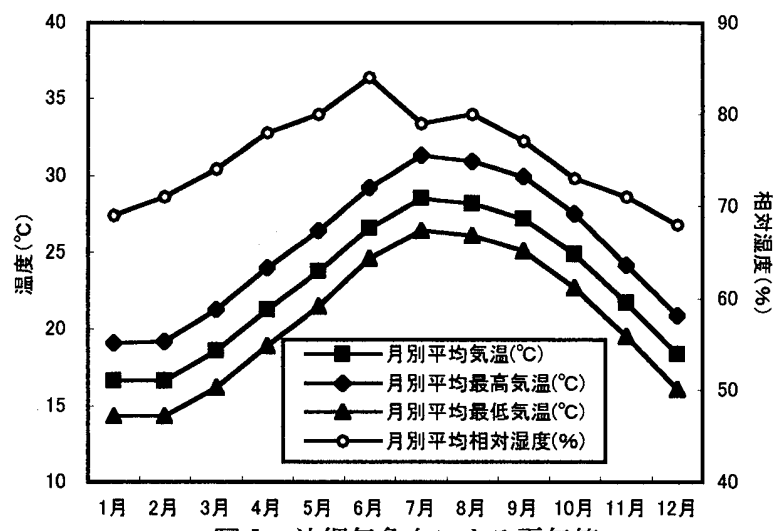

図 1 沖縄気象台による平年值

表 1 各測定対象住宅における測定項目

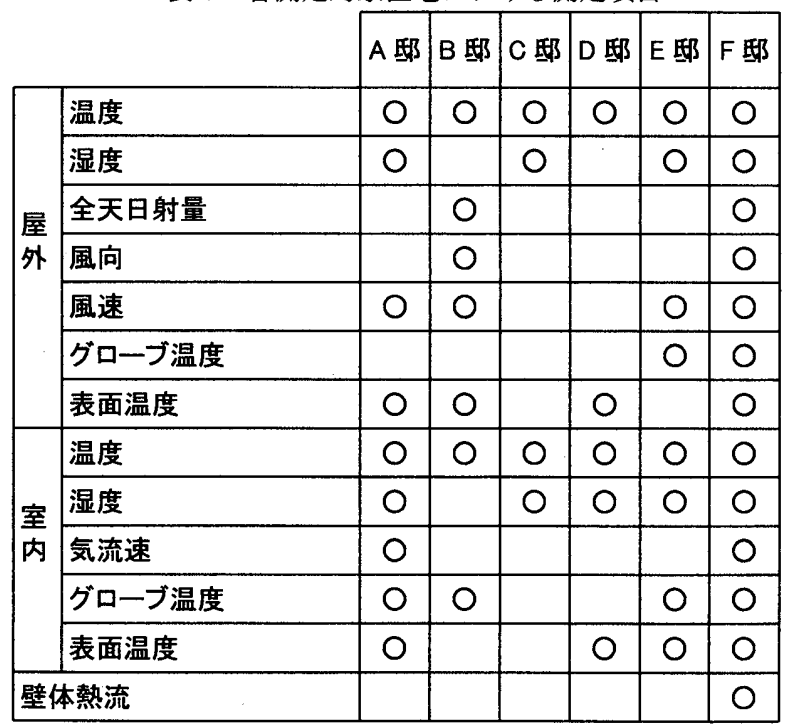

表 2 測定対象住宅の概要と代表日および選出した測定点

\begin{tabular}{|c|c|c|c|c|c|c|c|}
\hline 対象住宅 & 建 物 概 要 & 建造年代 & 所在地 & 気象台 & の位置 & 代表日 & 選出した測定点 \\
\hline$A$ 邸 & 木造軸組赤瓦蕞 & 1720 年頃 & 北中城村 & 東北東 & $14.0 \mathrm{~km}$ & 2001 年 7 月 21 日 & 二番座 \\
\hline $\mathrm{B}$ 邸 & 木造軸組セメント瓦茸 & 1950 年代 & うるま市 & 北東 & $25.2 \mathrm{~km}$ & 1995 年 9 月 1 日 & 瓦屋二番座，RC 造 \\
\hline C 邸 & 初期 RC 造 & 1950 年代 & 宜野湾市 & 北東 & $9.6 \mathrm{~km}$ & 2006 年 7月 2 日 & 室内 \\
\hline $\mathrm{D}$ 邸 & 一般 RC 造 & 1980 年代 & 宜野湾市 & 東北東 & $8.9 \mathrm{~km}$ & 2001 年 7 月 25 日 & 一階居室, 一階寝室, 二階居室 \\
\hline E矨 & ピロティ型 RC 造 & 1990 年代 & 西 原 町 & 東北東 & $8.0 \mathrm{~km}$ & 1999 年 10 月 14 日 & ピロティ空間, 室内上部, 室内下部 \\
\hline $\mathrm{F}$ 邸 & 省エネルギ一型 RC 造 & 1990 年代 & 浦 添 市 & 北東 & $7.1 \mathrm{~km}$ & 1996 年 8 月 20 日 & 一階中央, 二階中央 \\
\hline
\end{tabular}




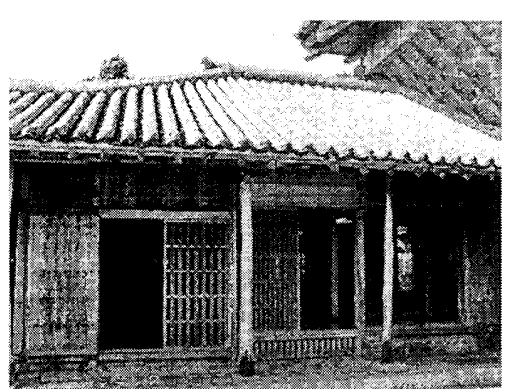

[A] $A$ 邸

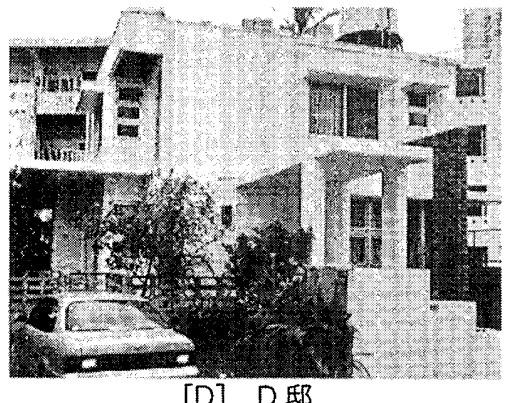

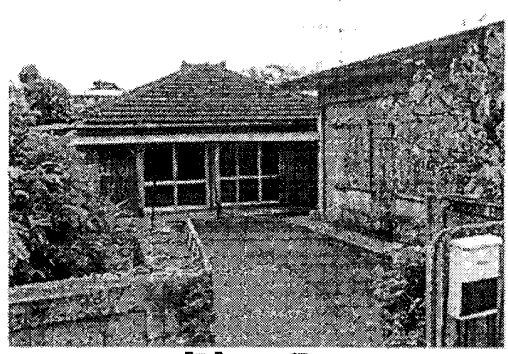

[B] B 邸

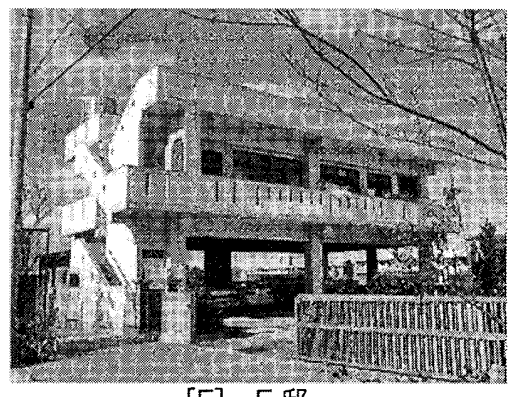

[E] E 邸

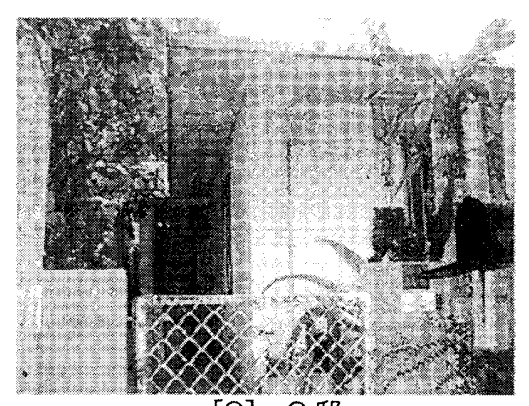

[C] C 邸

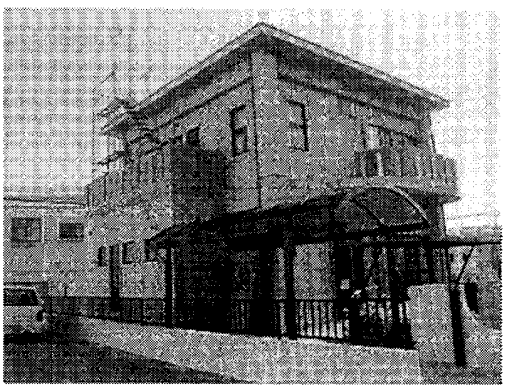

[F] $F$ 邸

図 2 測定対象住宅の外観

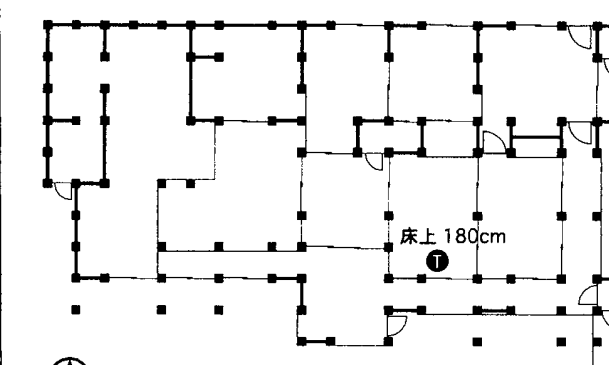

(1)
[A] A 邸

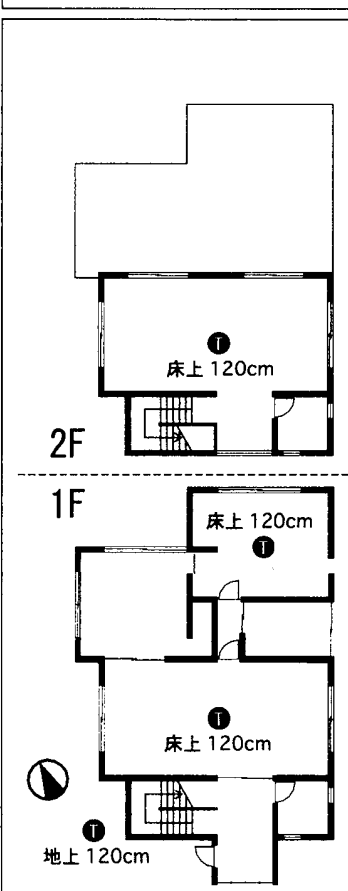

[D] D 邸

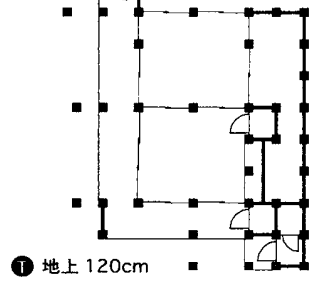

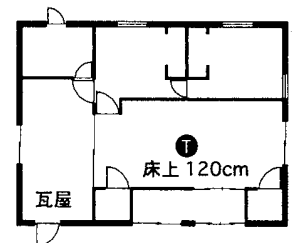

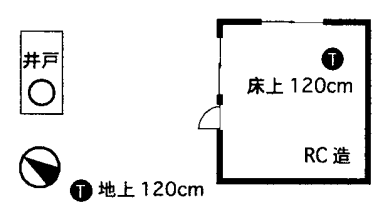

[B] $B$ 邸

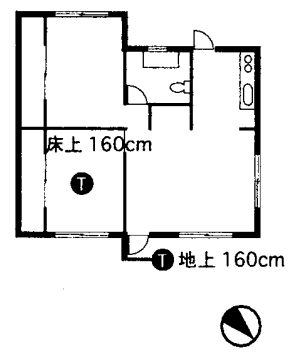

[C] C 邸

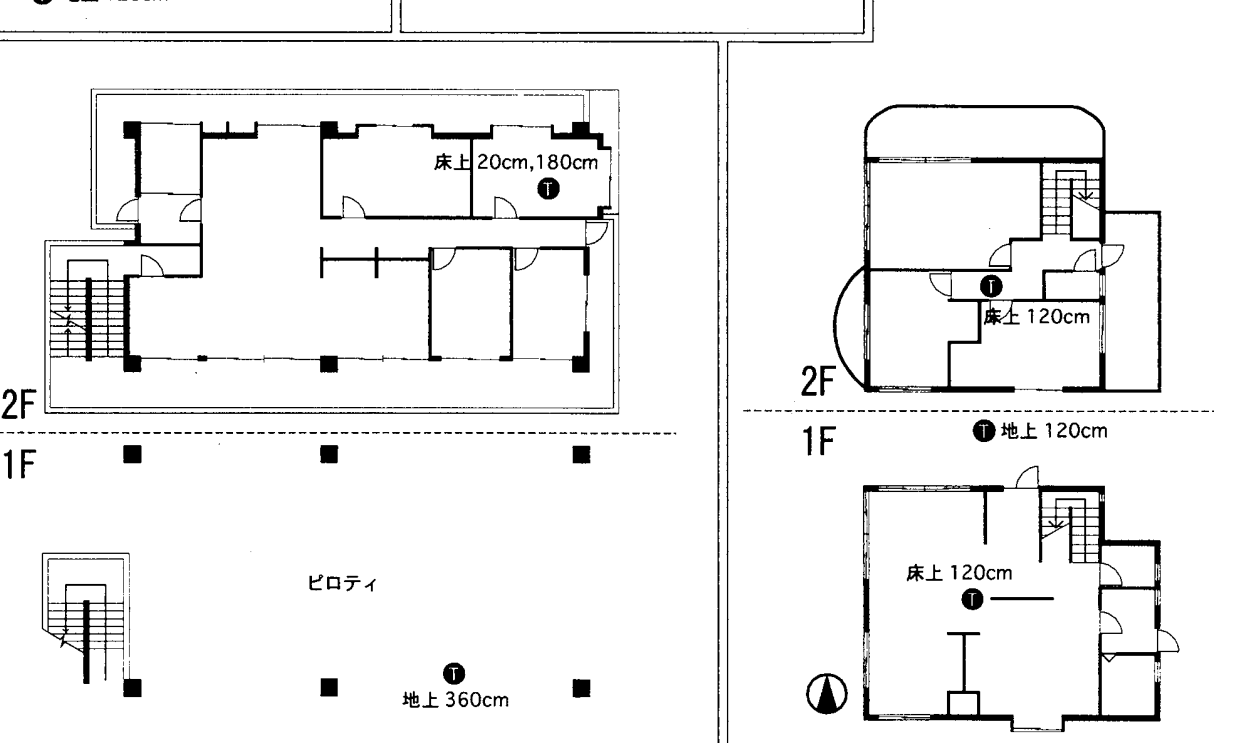

D

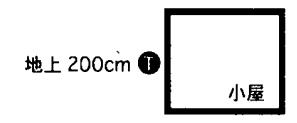

[E] E 邸

[F] $F$ 邸

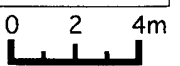

図 3 測定対象住宅における測定点配置図 


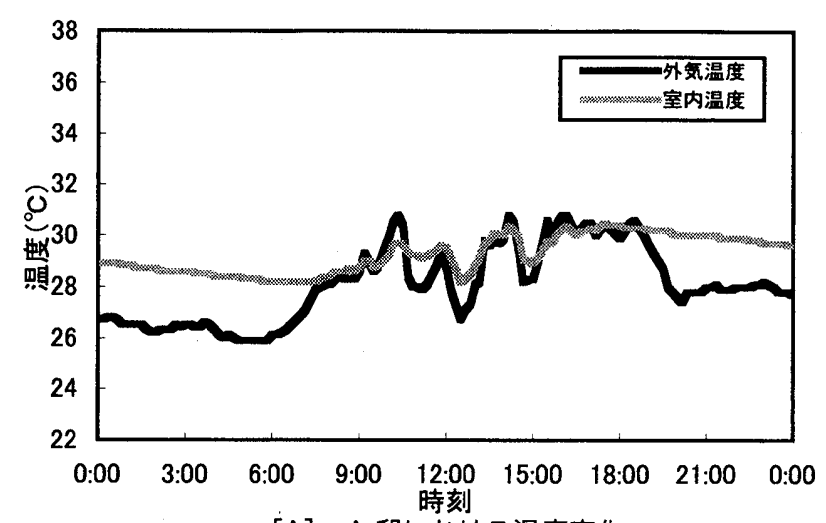

[A] A 邸における温度変化

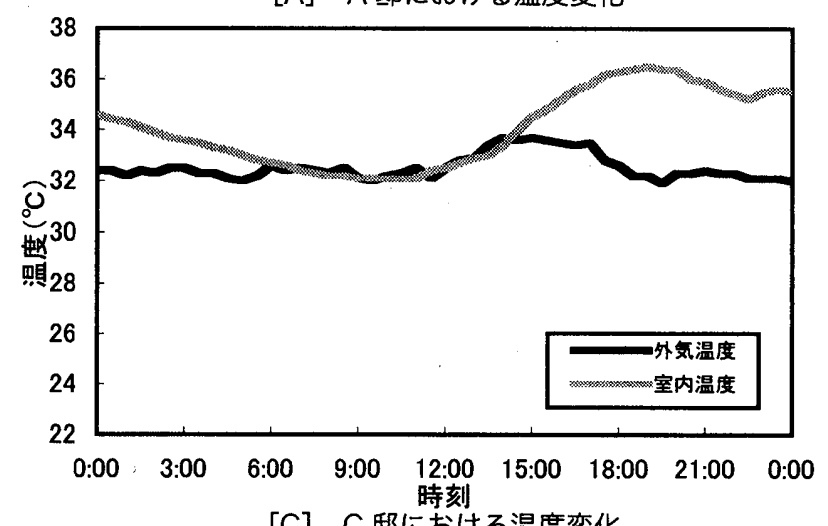

[C] C 郅における温度変化

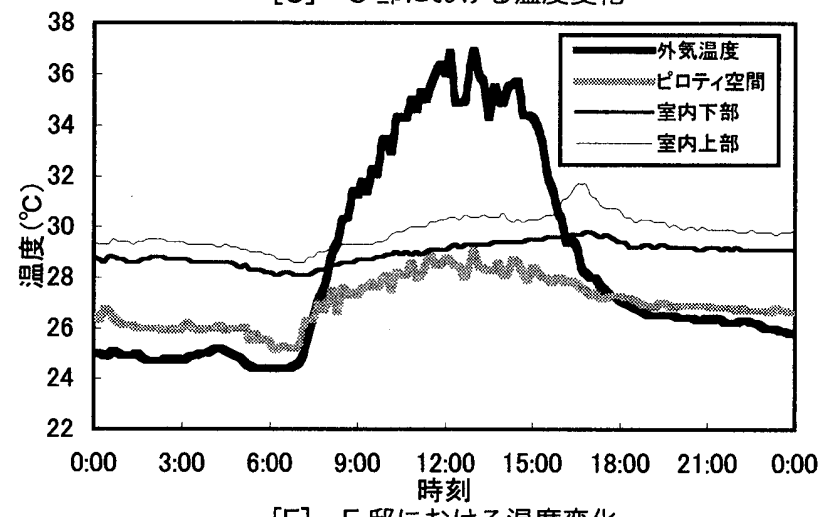

[E] E 邸における温度変化

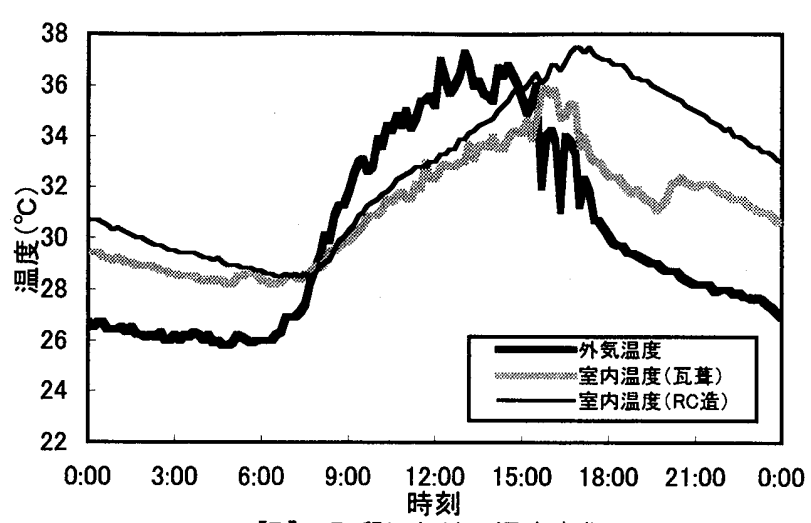

[B] B 邸における温度変化

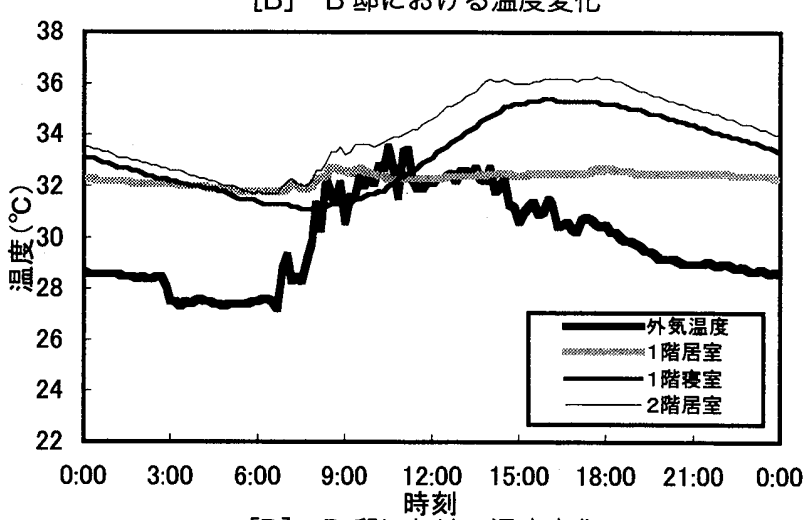

[D］Ｄ邸における温度変化

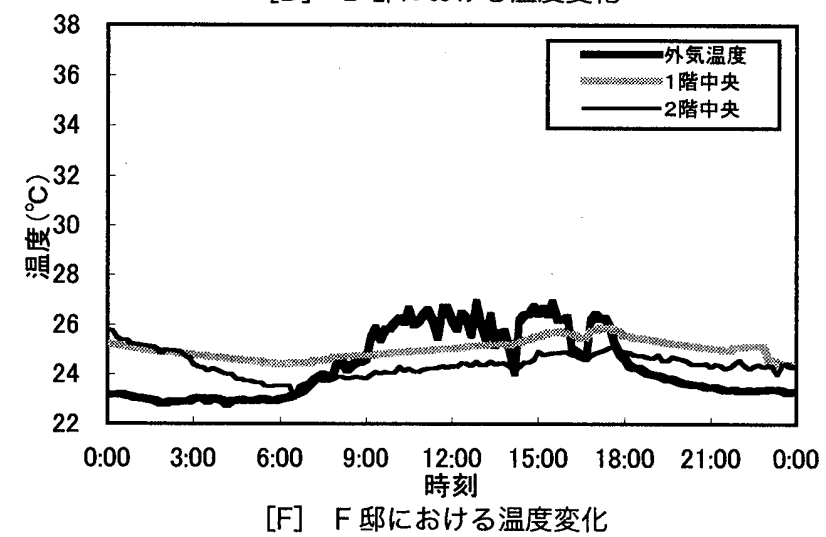

[F] F 邸における温度変化

図 4 各測定対象住宅における外気温度と室内温度の変化

階南側に一階部分の約半分の面積のベランダを持つ。 RC 造住宅は 1960 年代に入り沖縄の住宅の主流となり, 現在も住宅の大半を占 める。本研究では現在の沖縄の一般的な住宅としての位置づけで ある。

2001 年 7 月 22 日から 28 日までの期間と 9 月 12 日から 19 日ま での期間, $\mathrm{T}$ 型熱電対による室内温度, 外気温度, 表面温度, 高分 子型湿度計による室内湿度の測定を行っている。

\section{$3.5 E$ 邸}

西原町に位置する住宅で， RC 造二階建てのピロテイ建築である (図 $2[\mathrm{E}]$ )。一階部分に壁を持たず，二階の住居部分も窓・ドアに よる開口部が多く開放的な設計となっている。本研究では，沖縄に おいて現在多く見られる RC 造ピロティ建築の代表的な住宅として の位置づけである。

1999 年 10 月 13 日から 19 日までの期間, 自己記録型温湿度計に よる室内温度・湿度, 外気温度・湿度, グローブ温度, 放射温度計に よる表面温度，熱式風速計による風速の測定を行っている。

\section{$3.6 \mathrm{~F}$ 邸}

浦添市に位置する住宅会社のモデルハウスである (図 $2[F]) 。 二$ 重壁体による通気層を持つ $\mathrm{RC}$ 造二階建て住宅で，同社敷地内に設 置されている。二重壁の外壁が鉄筋コンクリートで, 内壁は石高 ボード下地の上ビニールクロス仕上げであり，両者間の通気層の幅 は約 $8 \mathrm{~cm}$ である。外壁および内壁に手動で開閉できるアルミ製の がらりが各室に設けられており，通気層と屋外・室内の空気の流れ を制御できる仕組みを持つ。本研究では，かつて一般的であった通 風というパッシブクーリング手法を取り入れた $\mathrm{F}$ 邸の住居形態を沖 縄の住宅の変遷の一部と捉え, 他の住宅と同一の系列の中で比較検 討を行う。

1996 年 8 月 17 日から 20 日までの期間と 1997 年 7 月 31 日から 8 月 4 日までの期間, $\mathrm{T}$ 型熱電対による室内温度, 外気温度, グロー ブ温度, 表面温度, 高分子型湿度計による室内湿度, 屋外湿度, 熱流 計による壁体熱流，また屋上においてネ才型全天日射計による全天 日射量, プロペラ型風速計による風向・風速の測定を行っている。 


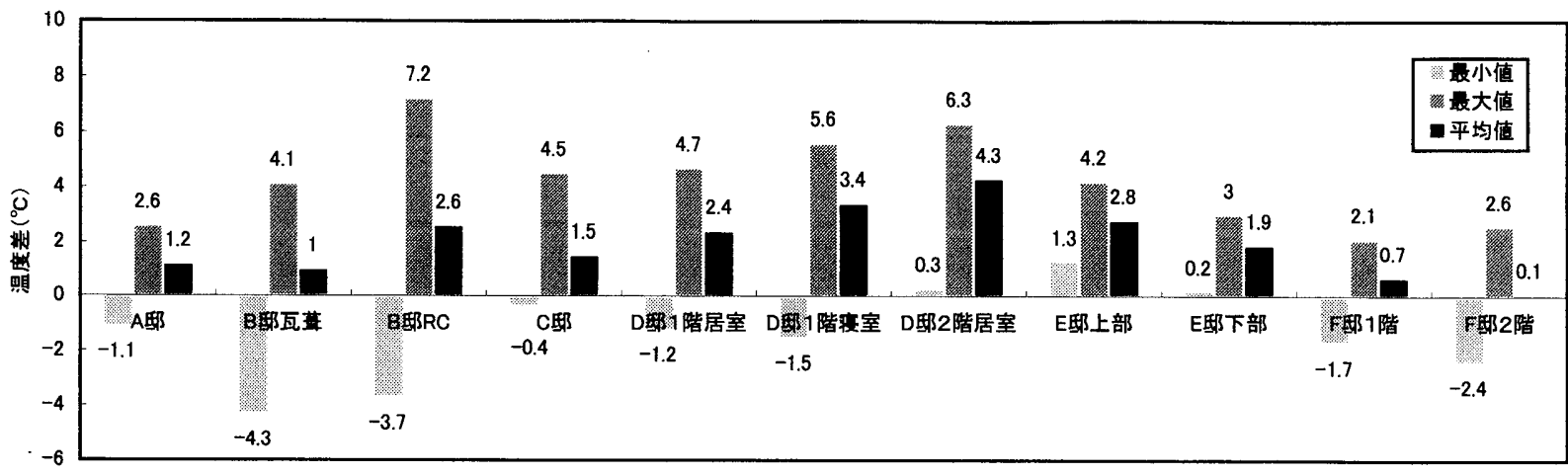

図 5 各測定住宅における温度差（室内温度－外気温度）

\section{4. 実測結果}

\section{1 各測定の状況}

本研究において, 測定開始時の建物の使用状態は通常の状態であ り, 通風や空調機の使用状態を測定に合わせて変更していない。ま た，熱容量の大きな住宅に関しては，建造されてから十分な時間が 経過しているため定常的に落ち着いた状態と捉えいてる。各測定 において，気象状況の良好な 1 日のデータを取り上げ, 測定点の中 から外気温度と代表的な室内の測定点を選び熱環境の検証を行う。 各測定での代表日と選出した測定点は表 2 に示した通りである。

\subsubsection{A 邸}

母屋の中央に位置する二番座と呼ばれる部屋の中央の温度と外 気温度の日変動を図 4 [A] に示す。13:00 頃に $0.1 \mathrm{~mm}$ に満たない 降雨があり，それに伴う外気温度の低下が見られる。朝 8:00 から 夕方 18:00 頃までの時間帯において, 室内温度は外気温度の変動に 敏感に反応し，ほぼ同時に振幅の向きを変えている。外気温度が低 い早朝と夜間では，室内温度は緩やかに低下している。

\subsubsection{B 邸}

対象建物の瓦屋の二番座の室内温度と隣接する $\mathrm{RC}$ 造の物置の室 内温度, 外気温度の日変動を図 4 [B] に示す。朝の温度上昇は瓦 屋, $\mathrm{RC}$ 造共に外気温度より約 2 時間遅い。この時刻から 15:00 頃 までの時間帯において, どちらの室内温度も外気温度より低い值で 上昇を続ける。外気温度が 13:00 頃にピークに達するのに対し，瓦 屋では 16:00 頃， RC 造では 17:00 頃にピークに達する。

\subsubsection{C 邸}

$\mathrm{C}$ 邸の外気温度と室内温度の日変動を図 4[C] に示す。6:00 頃 から外気温度が最大となる 15:00 頃までの時間帯において外気温 度と室内温度は比較的近い值で推移する。室内温度はピークに達 する 19:00 頃まで一気に上昇し，すぐに下降を始める。ほとんど変 動しないのは上昇の始まる前の 2 時間程度である。

\subsubsection{D 邸}

一階の南側に位置する寝室と中央に位置する居室，二階の居室， 外気温度の日変動を図 4 [D] に示す。一階居室の変動幅が他の 2 室 に比べて極端に小さい。一階居室は南面する空がなく日射の影響を 受けにくいため, 室内温度が上昇しにくいと考えられる。これに対 して，南側に窓を持つ一階寝室と二階居室は日射の影響が大きく， 2 室とも同様の変動を見せている。また，この 2 室はピークに達し た後すぐに下降せず，一階璌室は約 2 時間，二階居室は約 4.5 時間 最大值付近の值を維持した後に下降を始めている。二階居室は朝 6:00 頃の約 1 時間を除き常に他より高い値を示している。
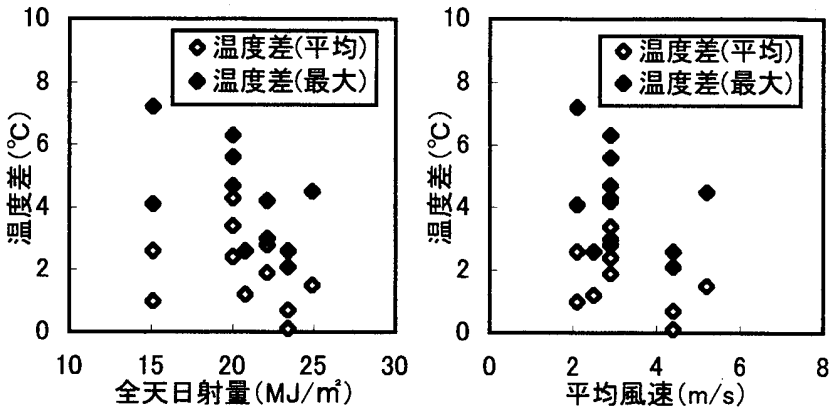

図 6 全天日射量と温度差の相関 図 7 平均風速と温度差の相関

\section{$4.1 .5 \mathrm{E}$ 邸}

室内の床面より $20 \mathrm{~cm}$ と $180 \mathrm{~cm}$ の点と外気温度, ピロティ空間 の温度をまとめた日変動を図 4 [E] に示す。外気温度は物置小屋軒 下，地上 $200 \mathrm{~cm}$ の点で測定を行ったが，亜鉛鉄板製の庇からの輻射 の影響を受けてかなり高い值を示している。一方，年間を通して常 に日陰となるピロティ空間内の地上 $360 \mathrm{~cm}, 2$ 階床スラブから $10 \mathrm{~cm}$ 下の点では温度があまり上昇せず，外気温度との最大温度差

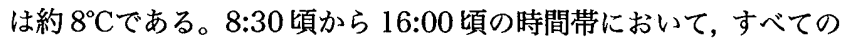
測定点の温度が外気温度よりも低い值で変動している。温度上昇の ピークがピロティ空間と外気温度では 13:00 頃であるのに対し, 室 内の 2 点は 17:00 頃である。半屋外空間であるピロティ空間の温度 は外気温度の変動に概ね追随した変動を示す。室内温度の 2 点は常 に下部より上部が高い值を示しており安定層が見られる。室内温度 の変動幅は一日を通して $3^{\circ} \mathrm{C}$ 未満であり, 下部では $2^{\circ} \mathrm{C}$ 未満である。 $4.1 .6 \mathrm{~F}$ 邸

外気温度,一階中央, 二階中央の温度の日変動を図 $4[\mathrm{~F}]$ に示す。 外気温度が他の測定より低めであるのは降雨の影響を受けているた めと思われる。また，測定点が北側に位置しており植栽の影響を受 けている可能性も考えられる。外気温度の変動に対して室内温度の 変動は緩やかだが, 外気温度に対する室内温度の反応は比較的早 い。室内温度に関して, 深夜を除く殆どの時間带において一階より 二階の方が高い值を示している。B 邸, C 邸, D 邸, E 邸の $\mathrm{RC}$ 造住 宅で見られるような外気温度と室内温度の変動の時間差が $\mathrm{F}$ 邸では あまり見られない。通気層の排熱効果が壁体から室内への放熱を軽 減しているためと思われる。

\section{2 実測結果のまとめ}

$\mathrm{A}$ 邸, $\mathrm{C}$ 邸, D 邸において, 室内温度が一日中外気温度と同等か 高い状態であることがわかる。また，ほぼ全ての住宅において，夜 間の外気温度の低下に対する室内温度の低下が小さい。これは渡 
辺らの夏季蒸暑地における戸建住宅の自然状態での測定 ${ }^{1)}$ と同じ傾 向である。しかし $\mathrm{B}$ 邸， $\mathrm{E}$ 邸， $\mathrm{F}$ 邸では，日中の室内温度が外気温 度よりも低いのが明確である。

\section{5. 温度差による熱環境の評価}

室内熱環境の評価において, 最重要要素は温度であると考えられ る。また, 住宅の防暑性能を考える上で内外温度差は最も重要で明 快な指標である。実測で得られた外気温度が建物周辺の外気温度 を代表すると考え, これらの実測調査の結果をもとに建物の内外温 度差による住宅の室内熱環境の評価を行う。

各測定刘象住宅の実測調査から得られたデー夕による室内と屋 外の温度差 (室内温度 - 外気温度) の最小值, 最大值, 平均値を図 5 , 外気温度や室内温度への影響が大きいと考えられる全天日射量 と温度差, 風速と温度差をそれぞれ図 6 , 図 7 に示す。日射量, 風 速の測定がない住宅においては気象台のデー夕を用いた。温度差 の最大值や平均値が小さいほど一般的に言われる「熱のこもらな い」住宅であると言える。最小值に負の值が見られるが，これは室 内温度が外気温度よりも低い場合の最大值ということになる。

温度差が大きく現れるのは, 外気温度と室内温度の変動に時間差 が生じる場合が多い。住宅の材料は一般的に木材とコンクリート がその大部分を占めることになるので, 熱容量の大きいコンクリー 卜造の住宅にその傾向が強くなる。本研究においても B 邸 RC 造, $\mathrm{C}$ 邸，D邸，E 邸において顕著に表れている。

図 5 において, B 邸 RC 造を除き左から右へと住居形式が変化し て来たことになり, 使用される材料は木材からコンクリートへと変 化している。温度差という観点から建物の熱的性能を評価すれば, 一般的な RC 造である D 邸までは住宅の熱的性能は悪くなってい る。しかし, ピロティ建築やパッシブクーリングの手法を取り入れ た住宅が出てきたことにより熱的性能は向上して来たと言える。

図 6, 図 7 において, 全天日射量と温度差, 風速と温度差の相関 はあまり見られない。日射量と風速が屋外と室内の温度差に及ぼ す影響は小さく，建物自体がその要因であることがわかる。

\section{6. まとめ}

本研究では沖縄の住居形態の変遷を追い, 歴史的建造物や代表的 な形態の住宅において熱環境の実測調査を行い, その熱的性能の変 遷を調べるため, 室内と屋外の温度差という観点から各住宅の熱環 境の評価を行った。完全に開放的であった昔の木造住宅では室内 温度と外気温度の差が小さかったが, それが RC 造に移ると悪化 し, 最近になってパッシブクーリング化されて, 昔の木造に近づい ていることが明確に示された。健康的で省エネルギーな住宅作り を目指す上で, これまでの住宅の熱環境を評価することは重要であ り，その基礎データの構築となった。

沖縄における住居形態は建築材料の不足や様々な要因により, 快 適性を追求して発展して来たわけではなく, 現在の主流である $\mathrm{RC}$ 造住宅も耐風恒久建築として導入されたものであり, 蒸暑への対策 ではない。しかし，ピロティ建築やパッシブクーリングシステム 等, $\mathrm{RC}$ 造での熱的快適性の追求が行われ始めていることも事実で ある。亜熱帯蒸暑地域である沖縄においては，十分とは言えないま
でも，高断熱高気密でない開放的なパッシブクーリング手法である 程度の効果を示している。今後もこの方針で省エネルギーと快適性 を追求することは有効である。

謝辞

本研究において実測調査に快く承諾していただいた各住宅の皆様 に深く感謝致します。実測調査の際には各測定年度の琉球大学堤研 究室の卒論生および大学院生に多大な協力を頂きました。本研究は 文部科学省科学研究費補助金基盤研究 (B) (研究課題番号: 16360293-00, 研究代表者: 堤純一郎, 研究課題名「亜熱帯沖縄の 生活と気候に適合する真の環境共生健康住宅に関する研究」）によ り実施されました。ここに記して謝意を表します。

参考文献

1) 渡辺康徳, 渡辺俊行, 龍有二, 赤司泰義, 川上司 : 夏期蒸暑地における断 熱気密住宅の室内熱環境に関する調査研究, 日本建築学会計画系論文集 第 495 号, pp.21-92, 1997.5

2) 高瀬秀芳, 渡辺俊行, 尾崎明仁 : 季間蒸暑地地域における断熱気密住宅の 熱環境性能, 日本建築学会計画系論文集 第 572 号, pp.9-16, 2003.10

3) 赤坂裕, 黒木荘一郎, 小原聡司 : 奄美大島の木造戸建て住宅の夏季及び冬 季の温熱環境実測調査, 日本建築学会大会学術講演梗概集, pp.1043-1044, 1992.8

4) 浦野良美, 渡辺俊行, 龍有二ほか: 蒸暑地における付設地下室住宅の涼房 効果, 日本建築学会九州支部研究報告 第 31 号・2, pp.141-152, 1989.3

5) 石原修ほか：パッシブエアサイクル住宅の温熱環境に関する実験的研究, 日本建築学会中国・九州支部研究報告 第 8 号・2,pp.249-252, 1990.3

6) 赤坂裕, 黒木荘一郎, 小原聡司, 曾我和弘: ファームコアパネル棟を主と する 4 棟の試験棟のパッシブ下における温熱居住環境の実測 蒸暑地域の 住宅の温熱環境に関する調查研究 その 1 , 日本建築学会計画系論文集 第 497 号, pp.15-22, 1997.7

7) 浦野良美, 渡辺俊行, 林徹夫, 内山明彦 : 九州北部に残る伝統的民家の熱 環境に関する調査研究, 日本建築学会計画系論文報告集第 371 号, pp.27-37 1987.1

8) 大塚信哉, 山口水城, 後藤剛史, 古川修文, 出口清考 : 沖縄における伝統 的民家と戦後の RC 造住宅との住居環境に関する研究 (その 1) 研究概要と 調查家屋, 日本建築学会大会学術講演梗概集, pp.101-102.1987.10

9) 古川修文, 山口水城, 出口清考, 大塚信㳦, 後藤剛史 : 沖縄における伝統 的民家と戦後の R C 造住宅との住居環境に関する研究 (その2) 夏期温熱環 境の計測, 日本建築学会大会学術講演梗概集, pp.31-32, 1987.10

10) 福島駿介, 小倉暢之, 山里将樹: 沖縄における木工系技術およびその継承 に関する研究 その 1 木造家屋の系譜, 日本建築学会大会学術講演梗概集, pp.139-140, 1985.10

11) 中島親寛, 池田孝之, 小倉暢之:戦後の沖縄における沖縄住宅公社による 米軍住宅建設プロセスと計画管理に関する研究, 日本建築学会計画系論文 集 第 566 号, pp.105-111,2003.4

12) 貫井光男 : 沖縄県におりる空洞ブロック使用材料の歴史的変遷, 日本建築 学会大会学術講演梗概集, pp.983-984, 1997.9

13) 小倉暢之:沖縄の外人住宅に関する研究, 第一住宅建設協会調査研究報告 書, 1992

14) 与儀清春, 萩原正三:沖縄住宅公社外人住宅における住まい方の変化, 日 本建築学会大会学術講演梗概集, pp.137-138,1997.9

15) 田上健一，小倉暢之, 福島駿介:住要求及び居住実態からみたピロティー 型戸建住宅の空間特性, 日本建築学会計画系論文集 第 522 号, pp.147-153, 1999.8

16) 沖縄県の住宅事情, 沖縄県, 1995

17) 沖縄大百科事典, 沖縄夕イムス社, 1983.5

注

注1) 沖縄において古代から按司時代 (グスク時代，12〜15 世紀）を経て戦前 まで存続した掘つ立て小屋住居を穴屋（アナヤー）と呼ぶ。古代は小屋全 体が半地下室的に造られた。按司時代の頃から柱に礎石を用い，壁には子 ニブ（山原竹を網代のように編んだもの）を二重にし，中に菜または茅を 詰め，屋根はキチ (小丸太) で小屋組みし茅あるいは竹茅 (篠竹) 莫きにし た。時代が下るにつれて柱は石柱 (イシバーヤ)に代わったものもあり，床 は土床藥敷きから竹床莜敷きや筵敷きになる。王府時代の敷地家屋の制限 令 $(1737$ 年) により庶民の住まいは昭和初期まで主にこの様式に制限され た。穴屋に対して茅または瓦幕きの本格的な木造軸組建築を貫木屋（邓チ ジャー)という。

注2) 2007 年 1 月に那羁市, 西原町, 中城村, 北中城村, 宜野湾市, 浦添市に おいて既存の住宅 350 戸を対象に実測調査を行った結果，約 $25 \%$ ティ建築であった。 